\title{
PENGARUH PENYARINGAN RUMPUT LAUT Euchema cottonii TERHADAP MUTU NORI
}

\author{
Emma Rochima*1, Kartika Irta Dewi ${ }^{1}$, Rusky Intan Pratama1 ${ }^{1}$ Nia Kurniawati ${ }^{1}$ \\ 1 Fakultas Perikanan dan IImu Kelautan, Universitas Padjadjaran \\ Jl. Raya Bandung - Sumedang Km 2, Jatinangor 45363, Jawa Barat, Indonesia \\ *Korespodensi: emma.rochima@gmail.com \\ (Diterima 13-02-2020 / Dipublikasi 13-02-2020)
}

\begin{abstract}
ABSTRAK
Penelitian ini bertujuan untuk menentukan perlakuan penyaringan rumput laut Euchema cottonii terbaik dalam pembuatan nori yang disukai panelis. Metode penelitian yang digunakan adalah metode eksperimental dengan lima perlakuan penyaringan rumput laut yang terdiri dari perlakuan $\mathrm{A}$ yaitu $0 \%$ (tanpa penyaringan), B yaitu 100\% penyaringan, C yaitu $90 \%$ penyaringan, $D$ yaitu $70 \%$ penyaringan dan $\mathrm{E}$ yaitu $50 \%$ penyaringan. Parameter yang diuji yaitu organoleptik dan kimia. Hasil penelitian yang paling disukai diperoleh berdasarkan parameter adalah perlakuan $D$ yaitu penyaringan $70 \%$ dengan nilai alternatif 6,80 yang menghasilkan nori dengan kenampakan warna kuning agak gelap $(6,4)$, tekstur agak kasar $(6,2)$, tercium aroma agak amis rumput laut yang khas $(5,6)$, rasa gurih dan asin $(7,4)$, dan memperoleh kadar air $(17,42 \%)$, kadar abu $(8,01 \%)$, kadar protein $(1,50 \%)$ dan kadar lemak (2,68\%).
\end{abstract}

Kata kunci: Euchema cottonii; penyaringan; nori; rumput laut

\section{ABSTRACT}

The aim of this research was to decide best treatment from Euchema cottonii seaweed filtration on preference of nori. The method used was experimental methods with five treatments the filtration of nori with treatment A 0\% (without fitration), B 100\% filtration, C 90\% filtration, D 70\% filtration and E 50\% filtration. The parameters observed were the organoleptic and proximate analysis. The best result based on the parameters was treatment $D$ with $70 \%$ filtration with alternative values 6,80 with the colour appearance was dark yellow $(6,4)$, rough texture and solid $(6,2)$, smell like seaweed $(5,6)$, tasteful and salted $(7,4)$ water content $(17,42 \%)$, ash content $(8,01 \%)$, protein content $(1,50 \%)$ and fat content $(2,68 \%)$.

Keyword: Euchema cottonii; filtration; nori; seaweed. 
PENDAHULUAN

Eucheuma cottonii adalah salah satu spesies alga merah yang banyak dibudidayakan di perairan Indonesia. Euchema cottonii biasanya diekstrak menjadi karaginan jenis kappa yang digunakan sebagai pengental dan pembuat gel di berbagai industri terutama industri pangan (Baga 2010). Karagenan juga dapat dimanfaatkan di berbagai industri lainnya seperti industri kosmetik, farmasi, tekstil, kertas, cat dan lain-lain (Rahmawati 2016). Menurut Rodrigues et al. (2015), Eucheuma cottonii memliki komposisi yang kompleks seperti polisakarida, protein, pospolipit, dan glikolipid. Polisakarida di dalam rumput laut berkisar $4 \%$ sampai $76 \%$ pada berat kering (Holdt et al. 2011).

Kandungan gizi yang dimiliki Euchema cottonii perlu dimanfaatkan secara maksimal dengan melakukan diversifikasi produk. Salah satu diversifikasi produk Euchema cottonii yaitu nori. Nori adalah makanan asal Jepang yang terdiri dari lembaran rumput laut yang dikeringkan atau dipanggang. Tekstur nori berbentuk kering halus (hoshi nori), berwarna hitam cerah dan berkilau karena kandungan pigmen Porphyran (sekitar $40 \%$ pada dried nori) (Riyanto 2014). Selain itu produk nori rumput laut merupakan salah satu diet sehat karena mengandung serat dan komponen bioaktif sehingga memberikan manfaat untuk kesehatan (Zakaria et al. 2015).

Proses penyaringan merupakan hal penting yang harus diperhatikan dalam pembuatan nori. Hal tersebut dikarenakan penyaringan dengan perlakuan terbaik dapat menghasilkan lembaran nori yang kokoh, tidak mudah rusak dan robek. Penyaringan juga berpengaruh pada tekstur nori, yaitu tekstur norinya kasar atau halus dan rata atau tidak rata. Penyaringan merupakan teknik yang dapat digunakan untuk memisahkan campuran yang ukuran partikel zat-zat penyusunnya berbeda.

Berdasarkan uraian tersebut perlu dilakukan penelitian mengenai pengaruh penyaringan rumput laut terhadap tingkat kesukaan nori. Tingkat kesukaan konsumen dapat diukur menggunakan uji organoleptik melalui alat indera. Kegunaan uji ini diantaranya untuk pengembangan produk baru (Jauzak 2012).

\section{METODE PENELITIAN}

\section{Bahan dan Alat}

Bahan-bahan yang digunakan pada penelitian ini yaitu rumput laut Euchema cottonii, $\mathrm{NaOH}$, gula pasir, air dan garam. Alat-alat yang digunakan pada penelitian ini yaitu timbangan digital, sendok, spatula, oven, loyang, saringan, blender, silicon paper. Alat yang digunakan untuk uji organoleptik 
yaitu piring plastik, lembar kuisioner, label dan kamera untuk dokumentasi.

\section{Prosedur Penelitian}

Metode penelitian yang digunakan adalah metode eksperimental terdiri dari lima perlakuan penyaringan puree (campuran rumput laut, gula pasir dan garam yang telah hancur). Perlakuan berdasarkan 5 formulasi, yaitu:

$A=0 \%$ penyaringan (kontrol)

$B=100 \%$ penyaringan

$\mathrm{C}=90 \%$ penyaringan

$\mathrm{D}=70 \%$ penyaringan

$\mathrm{E}=50 \%$ penyaringan

\section{Pembuatan Nori}

Pembuatan nori (modifikasi Teddy 2009) diawali dengan merendam rumput laut dalam air bersih 10 liter dan $\mathrm{NaOH}$ sebanyak $1 \mathrm{ml}$ yang bertujuan untuk melunakkan jaringan rumput laut agar memudahkan pada saat proses ekstraksi. Perendaman dilakukan selama 12 jam. Rumput laut yang telah direndam kemudian dicuci kembali dengan air mengalir selama 5 menit. Rumput laut yang sudah dibersihkan, gula pasir serta garam ditimbang dengan formula nori untuk satu perlakuan seperti yang dicantumkan pada Tabel 1.

$$
\text { Proses selanjutnya yaitu }
$$

penghancuran rumput laut, gula pasir dan garam menggunakan blender dalam waktu 7 menit hingga menjadi puree. Puree disaring sesuai 5 perlakuan kemudian dicetak pada loyang yang sudah diberi silicon paper agar bahan tidak lengket pada Loyang. Puree dikeringkan/dipanggang di lemari oven pada suhu $60^{\circ} \mathrm{C}$ selama 60 menit.

Tabel 1. Formula pembuatan nori

\begin{tabular}{ccc}
\hline Bumbu & $\begin{array}{c}\text { Presentase yang } \\
\text { Digunakan }\end{array}$ & Jumlah \\
\hline Rumput Laut & $85 \%$ & 102 \\
Euchema cottonii & $12 \%$ & gram \\
Gula pasir & $3 \%$ & 14,4 \\
& & gram \\
Garam & 3,6 gram \\
\hline
\end{tabular}

\section{Karakterisasi Sampel}

Pengujian organoleptik

Pengujian organoleptik (SNI 01-2346-

2006) dilakukan terhadap atribut tekstur, warna, rasa, dan aroma dengan menggunakan uji rating hedonik. Panelis yang digunakan dalam uji organoleptik sebanyak 20 orang panelis semi terlatih yaitu mahasiswa Fakultas Perikanan dan IImu Kelautan Universitas Padjadjaran sebagai. Pengukuran dilakukan berdasarkan tingkat kesukaan panelis terhadap lima formula produk yang digunakan. Skala yang digunakan pada uji rating hedonik ialah skala 1 sampai 7 yang terdiri dari: (1) sangat suka; (2) suka; (3) agak suka; (4) netral; (5) agak tidak suka; (6) tidak suka; (7) sangat tidak suka. Hasil dari uji hedonik tersebut dianalisis secara statistik menggunakan Uji Friedman dan Metode Bayes.

\section{Pengujian Proksimat}

Analisis proksimat mengacu pada AOAC 2005, dilakukan untuk memperoleh 
data kadar air, kadar abu, kadar lemak, kadar protein dan Analisis kadar air pada produk dengan hasil terbaik analisis organoleptik.

\section{HASIL DAN PEMBAHASAN \\ Kenampakan}

Hasil analisis uji hedonik dengan menggunakan uji Friedman terhadap kenampakan nori ditampilkan pada tabel 2. Pada Tabel 2 dapat diketahui penyaringan rumput laut $70 \%$ adalah perlakuan dengan nilai rata-rata tertinggi sebesar 6,4 dan menunjukkan bahwa kenampakan nori yang dihasilkan lebih menarik yaitu berwarna kuning agak gelap dan tidak terdapat banyak granul. Berbeda dengan penyaringan $0 \%$ memiliki rata-rata terendah yaitu 4,7 yang artinya kenampakan yang dimiliki tidak menarik sehingga tidak disukai oleh panelis yaitu dengan kenampakan kuning gelap kecoklatan dan terdapat banyak granul.
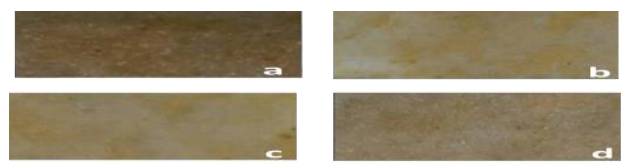

Gambar 1 Kenampakan produk nori pada tiap perlakuan;

a) Tanpa penyaringan

b) $100 \%$ Penyaringan

c) $90 \%$ Penyaringan

d) $70 \%$ Penyaringan

e) $50 \%$ Penyaringan

Hal ini diduga karena adanya pengaruh dari perlakuan penyaringan rumput laut yang berbeda-beda yaitu semakin sedikit rumput laut yang disaring, maka warna nori yang dihasilkan semakin berwarna coklat dan cenderung gelap, namun kenampakan yang paling disukai adalah pada perlakuan pernyaringan rumput laut $70 \%$ karena memiliki kenampakan warna kuning agak gelap dan terdapat granul yang tidak banyak. Kenampakan nori tersebut mendekati nori komersil yaitu memiliki karakteristik kenampakan agak gelap.

Tabel 2. Kenampakan nori pada tiap perlakuan

\begin{tabular}{ccc}
\hline Penyaringan (\%) & Nilai Median & Rata-rata \\
\hline 0 & 5 & $4,7 \mathrm{a}$ \\
100 & 7 & $5,7 \mathrm{ab}$ \\
90 & 5 & $5,5 \mathrm{ab}$ \\
70 & 7 & $6,4 \mathrm{~b}$ \\
50 & 5 & $5,1 \mathrm{ab}$ \\
\hline
\end{tabular}

Keterangan: nilai yang diikuti huruf yang sama secara vertikal menunjukkan tidak berbeda nyata pada taraf $5 \%$

\section{Aroma}

Hasil analisis uji hedonik dengan menggunakan uji Friedman terhadap aroma nori menunjukkan bahwa perlakuan penyaringan pada rumput laut tidak memberikan pengaruh nyata terhadap aroma nori. Hal tersebut disebabkan karena aroma nori yang dihasilkan tidak memiliki perbedaan. Tabel 3 menunjukkan bahwa semua perlakuan penyaringan memiliki nilai rata-rata yang tidak jauh berbeda namun aroma nori hasil penelitian masih dapat diterima oleh panelis. 
Tabel 3 Aroma nori pada tiap perlakuan

\begin{tabular}{ccc}
\hline $\begin{array}{c}\text { Penyaringan } \\
(\%)\end{array}$ & Nilai Median & Rata-rata \\
\hline 0 & 5 & $5 \mathrm{a}$ \\
100 & 5 & $5,5 \mathrm{a}$ \\
90 & 5 & $5,6 \mathrm{a}$ \\
70 & 5 & $5,6 \mathrm{a}$ \\
50 & 5 & $5,3 \mathrm{a}$. \\
\hline
\end{tabular}

Keterangan: nilai yang diikuti huruf yang sama secara vertikal menunjukkan tidak berbeda nyata pada taraf $5 \%$.

Rata-rata tertinggi ada pada penyaringan $90 \%$ dan $70 \%$ yaitu 5,6 yang artinya aroma pada kedua perlakuan tersebut paling disukai dibandingkan dengan ketiga perlakuan lainnya. Hal tersebut disebabkan karena perlakuan penyaringan $90 \%$ dan $70 \%$ menghasilkan nori dengan aroma agak bau amis yang khas yang sama dengan aroma nori komersial. Penyaringan $90 \%$ memiliki aroma yang hampir sama dengan penyaringan $100 \%$ yaitu aroma agak amis khas rumput laut tapi jika dibandingkan dengan penyaringan 100\% panelis lebih menyukai aroma pada penyaringan $90 \%$ dari pada penyaringan $100 \%$ karena pada penyaringan $90 \%$ terdapat campuran bahan $10 \%$ yang tidak disaring yang membuat aroma 90\% penyaringan lebih disukai dibandingan penyaringan $100 \%$.

Pernyataan tersebut dibuktikan dengan nilai rata-rata aroma pada perlakuan $100 \%$ yaitu 5,5 , beda tipis dengan penyaringan $90 \%$. Perlakuan pada penyaringan $0 \%$ dan $50 \%$ menghasilkan aroma amis yang sedikit tajam sehingga kedua perlakuan tersebut memiliki nilai ratarata dua terendah, yakni 5 dan 5,3 .

\section{Tekstur}

Hasil analisis uji hedonik dengan menggunakan uji Friedman terhadap tekstur nori menunjukkan bahwa perlakuan penyaringan pada rumput laut memberikan pengaruh nyata terhadap tekstur nori. Tabel 4 menunjukkan bahwa penyaringan $0 \%$ memiliki nilai rata-rata 4,5 yaitu dengan tekstur sangat kasar, tidak rata, rapuh, tidak mudah rusak dan robek hal tersebut karena tidak adanya campuran bahan yang disaring. Selanjutnya pada penyaringan $100 \%$ memiliki nilai rata-rata 5,8 dengan tekstur sangat halus, rata, tidak mudah rusak dan robek hal tersebut disebabkan tidak adanya campuran bahan yang tidak disaring. Tekstur nori pada penyaringan $90 \%$ memiliki rata-rata 5,1 yaitu halus, rata, tidak mudah rusak dan robek tetapi panelis lebih menyukai penyaringan $100 \%$ karena pada penyaringan $90 \%$ terdapat campuran bahan $10 \%$ yang tidak disaring yang menyebabkan tekstur pada penyaringan 90\% sedikit berbeda dibandingkan dengan tekstur pada penyaringan 100\%. Berbeda halnya dengan perlakuan penyaringan $70 \%$ yang memiliki nilai rata-rata 6,2 yaitu dengan tekstur yang agak kasar, kokoh, tidak mudah rusak dan robek karena adanya campuran bahan $30 \%$ yang tidak disaring. Nori pada 
perlakuan penyaringan $50 \%$ memiliki nilai rata-rata 5,8 yaitu dengan tekstur kasar, tidak rata, mudah rusak dan robek hal tersebut karena adanya campuran bahan $50 \%$ yang tidak disaring.

Tabel 4. Tekstur Nori Pada Tiap Perlakuan

\begin{tabular}{ccc}
\hline Penyaringan (\%) & Nilai Median & Rata-rata \\
\hline 0 & 5 & $4,5 \mathrm{a}$ \\
100 & 5 & $5,8 \mathrm{ab}$ \\
90 & 5 & $5,1 \mathrm{ab}$ \\
70 & 7 & $6,2 \mathrm{~b}$ \\
50 & 5 & $5,8 \mathrm{ab}$ \\
\hline
\end{tabular}

Keterangan: nilai yang diikuti huruf yang sama secara vertikal menunjukkan tidak berbeda nyata pada taraf $5 \%$.

Tekstur yang diharapkan dari produk nori ini adalah tekstur yang agak kasar dan tidak mudah robek. Penilaian panelis terhadap tekstur nori yang disukai ada pada penyaringan $70 \%$ dengan nilai rata-rata tertinggi 6,2 karena memiliki tekstur yang agak kasar, kokoh dan tidak mudah robek mendekati nori komersil. Tekstur nori hasil penelitian yang paling disukai sesuai dengan pernyataan yang diberikan Riyanto et al. (2014) yaitu nori Jepang bertekstur kasar dan menyerupai bubur kertas, kokoh dan tidak mudah rusak.

\section{Rasa}

Hasil analisis uji hedonik dengan menggunakan uji Friedman terhadap rasa nori menunjukkan bahwa perlakuan penyaringan pada rumput laut memberikan pengaruh nyata terhadap rasa nori. Pada tabel 5 dapat diketahui rata-rata rasa nori pada penyaringan rumput laut $0 \%$ adalah 6,1 dengan rasa sangat asin gurih dan agak manis, hal tersebut disebabkan banyaknya granul pada penyaringan $0 \%$. Rasa nori pada penyaringan rumput laut $100 \%$ memiliki ratarata 6,8 yaitu rasa tidak terasa asin dan agak manis, hal tersebut dikarenakan tidak adanya campuran bahan yang tidak disaring. Ratarata rasa nori pada penyaringan rumput laut 90\% adalah 5,9 dengan rasa hampir sama dengan penyaringan $100 \%$ yaitu rasa yang tidak terasa asin dan agak manis namun jika dibandingkan dengan penyaringan 100\% panelis lebih menyukai rasa dari penyaringan $100 \%$ karena pada penyaringan $90 \%$ terdapat campuran bahan 10\% yang tidak disaring yang menyebabkan rasa sedikit berbeda dengan penyaringan $100 \%$.

Tabel 5. Rasa nori pada tiap perlakuan

\begin{tabular}{ccc}
\hline Penyaringan (\%) & Nilai Median & Rata-rata \\
\hline 0 & 5 & $6,1 \mathrm{ab}$ \\
100 & 7 & $6,8 \mathrm{ab}$ \\
90 & 6 & $5,9 \mathrm{a}$ \\
70 & 7 & $7,4 \mathrm{~b}$ \\
50 & 7 & $6,8 \mathrm{ab}$ \\
\hline
\end{tabular}

Keterangan: nilai yang diikuti huruf yang sama secara vertikal menunjukkan tidak berbeda nyata pada taraf $5 \%$.

Berbeda dengan nori yang dimiliki oleh penyaringan rumput laut $70 \%$ memiliki rata-rata 7,4 dengan rasa rasa asin gurih yang pas dengan kombinasi rasa sedikit manis. Rata-rata rasa nori pada penyaringan 
rumput laut $50 \%$ yaitu 6,8 dengan rasa sangat asin gurih tetapi tidak lebih asin dari $0 \%$ penyaringan dan agak manis hal tersebut disebabkan adanya campuran bahan 50\% yang tidak disaring. Penyaringan $100 \%$ dan $50 \%$ memiliki nilai rata-rata yang sama yaitu 6,8 yang berarti panelis menyukai rasa yang dimiliki oleh nori pada kedua perlakuan tersebut.

\section{Analisis Byes}

Hasil perhitungan dengan mempertimbangkan kriteria kenampakan, aroma, tekstur dan rasa dengan penilaian terbaik nori dapat dilihat pada Tabel 6 . Berdasarkan perhitungan dengan metode Bayes didapatkan hasil bahwa nori dengan perlakuan penyaringan rumput laut dari semua perlakuan masih diterima atau disukai oleh panelis. Perlakuan $70 \%$ memperoleh nilai alternatif tertinggi yaitu 6,80 dengan demikian perlakuan penyaringan rumput laut $70 \%$ adalah nori yang paling disukai panelis. Hal ini diduga nori tersebut memiliki rasa asin yang gurih diperoleh karena penambahan garam pada bahan baku dengan kenampakan kuning kecoklatan, diikuti dengan tekstur yang kasar, kokoh, tidak mudah rusak dan robek akibat bahan yang disaring sebanyak $70 \%$ serta tidak memiliki perbedaan pada aroma nori karena aroma amis khas rumput laut masih dimiliki walupun tidak tajam.
Tabel 6. Matriks Keputusan Penilaian Nori

\begin{tabular}{ccccccc}
\hline \begin{tabular}{c} 
Penyari $\begin{array}{c}\text { ngan } \\
(\%)\end{array}$ \\
\cline { 2 - 5 }
\end{tabular} & $\begin{array}{l}\text { Kenam } \\
\text { pakan }\end{array}$ & $\begin{array}{l}\text { Arom } \\
\text { a }\end{array}$ & Tekstur & & $\begin{array}{c}\text { Nilai } \\
\text { Priorit } \\
\text { as }\end{array}$ & $\begin{array}{c}\text { Nilai } \\
\text { Alternatif }\end{array}$ \\
\hline 0 & 5,00 & 5,00 & 5,00 & 5,00 & 0,17 & 5,00 \\
100 & 7,00 & 5,00 & 5,00 & 7,00 & 0,22 & 6,47 \\
90 & 5,00 & 5,00 & 5,00 & 6,00 & 0,18 & 5,50 \\
70 & 7,00 & 5,00 & 7,00 & 7,00 & 0,23 & 6,80 \\
50 & 5,00 & 5,00 & 5,00 & 7,00 & 0,20 & 6,00 \\
\hline $\begin{array}{c}\text { Nilai } \\
\text { Kriteria }\end{array}$ & 0,23 & 0,10 & 0,17 & 0,50 & 1,00 & 29,77 \\
\hline
\end{tabular}

\section{Analisis Proksimat \\ Kadar Air}

Kadar air tertinggi terdapat pada nori hasil penelitian dengan perlakuan terbaik sebesar $17,42 \%$ sedangkan penyaringan $0 \%$ memiliki kadar air 15,16\%. Kadar air menunjukkan air yang teruapkan selama proses pengeringan. Faktor yang mempengaruhi perubahan kadar air tersebut salah satunya disebabkan oleh sifat fisik produk. Perlakuan penyaringan $70 \%$ memiliki tekstur yang kokoh dan tidak mudah robek atau rusak. Hal tersebut membuat kadar air pada penyaringan $70 \%$ lebih besar dibandingan kadar air pada penyaringan $0 \%$.

Kadar air yang di peroleh tidak jauh berbeda dengan kadar air nori dari tepung agar hasil ekstraksi rumput laut Gelidium sp. yang dilaporkan oleh Hasanah (2007), berkisar antara 17,64-27,45\%. Selain itu, pembentukan lembaran nori memanfaatkan sifat dari senyawa hidrokoloid sebagai pembentuk gel (Anggadiredja et al. 2010). Penambahan hidrokoloid yang semakin tinggi akan meningkatkan kekompakan matrik gel. 
Gel yang dihasilkan akan semakin kokoh dan menyebabkan air yang terperangkap semakin banyak sehingga air yang menguap selama proses pengeringan semakin kecil, hal ini menyebabkan terjadi peningkatan kadar air (Widyaningtyas dan Wahono 2015).

\section{Kadar Abu}

Nilai kadar abu perlakuan terbaik dengan penyaringan $70 \%$ sebesar $8,01 \%$ sedangkan kontrol dengan peyaringan $0 \%$ sebesar $13,90 \%$. Nori dengan penyaringan $0 \%$ memiliki nilai kadar abu lebih besar diduga karena nori pada penyaringan $0 \%$ memiliki banyak granul dibandingkan dengan penyaringan $70 \%$. Kadar abu dari suatu bahan menunjukkan kandungan mineral yang terdapat dalam bahan tersebut, kemurnian serta kebersihan suatu bahan yang dihasilkan. Abu tersebut disusun oleh berbagai jenis mineral dengan komposisi yang beragam tergantung pada jenis dan sumber bahan pangan (Andarwulan et al. 2011). Dapat dilihat semakin banyak rumput laut yang disaring, semakin rendah kadar abu nori yang dihasilkan. Hal ini dikarenakan rumput laut Euchema cottonii lebih kaya akan mineral seperti yang dijelaskan oleh Anggadiredja dkk (2010), bahwa beberapa jenis rumput laut mengandung lebih banyak vitamin, mineral penting seperti kalsium dan zat besi bila dibandingkan dengan sayuran dan buah-buahan.

\section{Kadar Protein}

Hasil analisis kadar protein nori perlakuan terbaik dengan penyaringan $70 \%$ sebesar $1,50 \%$ sedangkan kontrol dengan peyaringan $0 \%$ sebesar $1,44 \%$. Ariyanti (2005) dalam Asmara (2015) menyatakan bahwa kandungan protein rumput laut Euchema cottonii adalah berkisar 1,36\%2,08\%. Dapat disimpulkan semakin banyak rumput laut yang digunakan untuk disaring, semakin tinggi kadar protein nori yang dihasilkan, namun tidak terlalu signifikan. Hal ini menunjukkan penyaringan rumput laut menyebabkan kenaikan kandungan protein nori yang dihasilkan.

Kadar protein nori yang dihasilkan tidak jauh berbeda dengan hasil analisis nori komersial yang dilakukan yaitu berkisar 2,11\%. Rumput laut Euchema cottonii memiliki kandungan protein sebesar 5,12\%. Kandungan protein nori yang dihasilkan lebih rendah jika dibandingkan dengan kandungan protein bahan baku (Istini 1985). Hal ini dikarenakan pada proses pemasakan nori, bubur rumput laut (puree) dikeringkan hingga mencapai suhu $60^{\circ} \mathrm{C}$, pemanasan hingga suhu $60^{\circ} \mathrm{C}$ ini diyakini menyebabkan protein terdenaturasi. Menurut Kusnandar (2010), denaturasi protein dapat disebabkan oleh pemanasan pada suhu $55-75^{\circ} \mathrm{C}$. 


\section{Kadar Lemak}

Nilai kadar lemak nori perlakuan terbaik dengan penyaringan $70 \%$ sebesar $2,68 \%$ sedangkan kontrol dengan peyaringan $0 \%$ sebesar $2,59 \%$. Kandungan ini sangat dipengaruhi proses pencucian yang dilakukan selama pembuatan nori. Lin dan Park (1996) dalam Riyanto et al. (2014) menyampaikan bahwa saat proses pencucian, protein sarkoplasma, darah dan lemak menjadi larut dengan air. Adapun kandungan lemak untuk nori komersial merupakan lemak yang berasal dari Porphyra. Dawczynskiet et al. (2007) menyatakan bahwa kandungan lemak yang dimiliki nori dari Porphyra Jepang dan Korea mencapai 2,8\%, sedangkan dari Cina sebesar $1 \%$.

\section{SIMPULAN}

Nori dengan perlakuan paling disukai adalah perlakuan penyaringan $70 \%$ dengan nilai alternatif 6,80 dan memperoleh hasil uji proksimat yaitu; uji kadar air 17,42\%, kadar abu $8,01 \%$, kadar protein $1,50 \%$, kadar lemak $2,68 \%$.

\section{DAFTAR PUSTAKA}

Andarwulan, N., Kusnandar, F., Herawati, D. 2011. Analisis Pangan. Dian Rakyat. Jakarta.

Anggadiredja, J.T., Zatnika, A., Purwoto, H., Istini, S. 2006. Rumput Laut. Penebar Swadaya. Jakarta.
AOAC. 2005. Official Methods of Analysis of AOAC International. 18th ed. Assoc. Off. Anal. Chem., Arlington.

Asmara, A. 2015. Pengaruh Proporsi Daun Pegagan (Centella asiatica) dan Rumput Laut (Eucheuma cottonii) Terhadap Organoleptik Nori dan Aktivitas Antioksidan dengan Standar Butylated Hydroxyani sole (BHA). Skripsi. Fakultas Pertanian. Universitas Lampung. Bandar Lampung.

Baga, I. 2010. Rumput Laut di Indonesia. UNPAD Press. Jatinangor.

Dawezynski, C., Rainer, S., Gerhard, J. 2007. Amino acids, fatty acids and dietary fibre in edible seaweed product. Journal Food Chemistry. 103:891899.

Hasanah, H. 2007. Nori Imitasi dari Tepung Agar Hasil Ekstraksi Rumput Laut Merah Jenis Gelidium sp. Skripsi. Fakultas Perikanan dan IImu Kelautan. Institut Pertanian Bogor.

Holdt, S.L., Kraan, S. 2011. Bioactive compounds in seaweeds: functional food applications and legislation. Journal of Applied Physiology 23:543-597.

Istini, S. 1986. Manfaat dan pengolahan rumput laut. Jurnal Penelitian BPPT 4:52-55.

Jauzak, R. 2012. Fortifikasi Tepung Rumput Laut Pada Cookies Terhadap Tingkat Kesukaan. Skripsi. Fakultas Perikanan dan IImu Kelautan. Universitas Padjadjaran. Jatinagor.

Rahmawati, A. 2016. Pengaruh Perbandingan Penambahan Daun Katuk Dan Lama Pengeringan Terhadap Karakteristik Fruit Nori Pisang. Skripsi. Fakultas 
Teknik. Universitas Pasundan. Bandung.

Riyanto, T., Rohidin, G., Yusuf, B. 2014. Nori Imitasi Lembaran Dengan Konsep Edible Film Berbasis Protein Myofibrillar Ikan Nila. Jurnal Pengolahan Hasil Perikanan Indonesia. 17:262-279.

Rodrigues, D., Freitas, A.C., Pereira, L., Rocha-Santos, T.A.P., Vasconcelos, M.W., Roriz, M., Rodríguez-Alcalá, L.M., Gomes, A.M.P., Duarte, A.C. 2015. Chemical composition of red, brown and green macroalgae from Buarcos bay in central west coast of Portugal. Food Chemistry 183:197207.

Widyaningtyas, M., Wahono. 2015. Pengaruh Jenis Dan Konsentrasi Hidrokoloid (Carboxy Methyl, Cellulose, Xanthan Gum, Dan Karagenan) Terhadap Karakteristik Mie Kering Berbasis Pasta Ubi Jalar Varietas Ase Kuning. Jurnal Pangan dan Agroindustri. 3:417-423.

Zakaria, F.R. 2015. Pangan Nabati, Utuh dan Fungsional sebagai Penyusun Diet Sehat. Bogor. Indonesia. Orasi IImiah Guru Besar Institut Pertanian Bogor. 